\title{
Self-assessment for implementation of health promotion standards in hospitals, in medical education centers of Isfahan city
}

Atefeh Afshari

* Ph. D in health education \& health promotion, Department of Community of Health Nursing, School of Nursing and Midwifery, Isfahan University of Medical Sciences, Isfahan, Iran. (corresponding author): afshar.atefe@yahoo.com

Ahmad-ali Eslami

Associate Professor of health education \& health promotion, faculty of health, Isfahan University of Medical sciences, Isfahan, Iran.

Firoozeh Mostafavi

Associate Professor of health education \& health promotion, faculty of health, Isfahan University of Medical sciences, Isfahan, Iran.

\section{Elham Moazam}

Community Medicine proficient, Seidolshohada Hospital's cancer research center, Isfahan University of Medical sciences, Isfahan, Iran.

Mojtaba Golzari

MD, Vice-Chancellery for Clinical Affairs, Isfahan University of Medical sciences, Isfahan, Iran.

\section{Reza Etminan}

Ph. D in Nutrition, Vice-Chancellery in Finance and administration, Isfahan University of Medical sciences, Isfahan, Iran.

Received: 2019/12/3

Accepted: 2020/06/7

Doi: 10.29252/ijhehp.8.3.249

\section{ABSTRACT}

Background and Objective: The World Health Organization encourages hospitals to implement the health promoting hospital plan to improve health service quality. The aim of this study was to self-assessment status of health promotion in hospitals and identify existing strengths and gaps.

Materials and Methods: This study is a descriptive cross-sectional survey in which 9 educational hospitals were selected through census sampling. Health promotion self-assessment tools were used for the data collection. Data were analyzed using SPSS software and descriptive statistics.

Results: In most hospitals, the status were good regarding the health promoting policy in the hospital's mission, the availability of information to other patient organizations, providing information on high-risk diseases, recording patient information and follow-up training to patients and families in outpatient counseling, referral or during discharge. But the status were poor in terms of policies for participating in Health Promoting Hospitals Network, allocating specific funding for these services, revising guidelines for evaluating health promotion needs of patients, training new staff on hospital health promotion policies, implementing staff smoking cessation programs, Staff awareness on the organization's health promotion policy, a written plan to work with partners, and a specific process for exchanging patient information between organizations to continue patient care. Other standards evaluated average in most hospitals.

Conclusion: The average evaluation of most elements of standards indicates the unorganized implementation of some health promotion activities in hospitals. It is essential to organize and reinforce existing on-going activities, regular selfassessment of health promotion activities, and design interventions based on self-assessment results.

Keywords: Health promoting hospitals, health promotion, self-assessment Paper Type: Research Article.

Citation (Vancouver): Afshari A, Eslami A, Mostafavi F, Moazam E, Golzari M, Etminani R. Self-assessment for implementation of health promotion standards in hospitals, in medical education centers of Isfahan city. Iran J Health Educ Health Promot. Spring 2020;8(3): 249-260. [Persian]x

- Citation (APA): Afshari A., Eslami A., Mostafavi F., Moazam E., Golzari M., Etminani R. Self-assessment for implementation of health promotion standards in hospitals, in medical education centers of Isfahan city. Iranian Journal of Health Education \& Health Promotion., 8(3), 249-260. [Persian] 


\section{خود ارزيابى اجراى استانداردهاى ارتقاى سلامت در بيمارستانها در مراكز آموزشى درمانى شهر اصفهان}

\section{0}

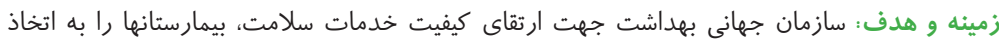

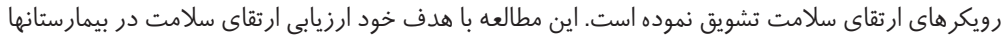

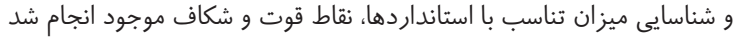

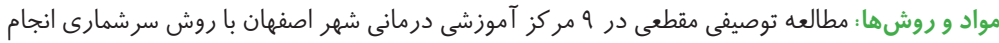

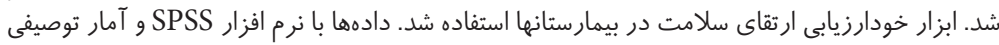

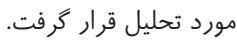

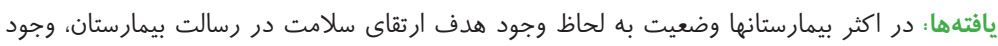

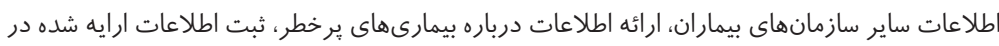

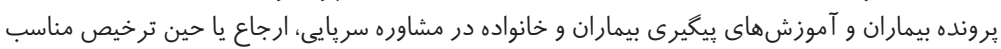

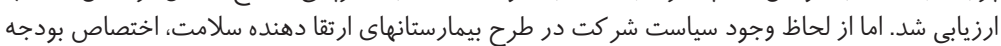

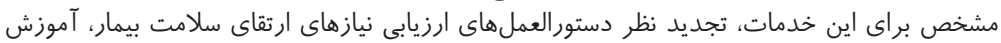

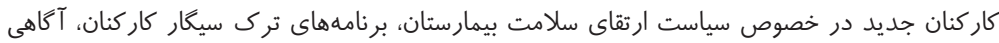

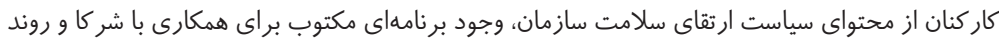

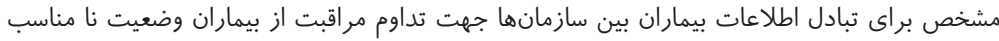

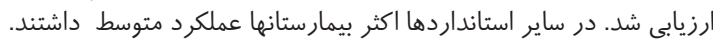

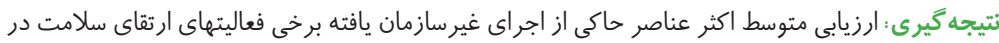

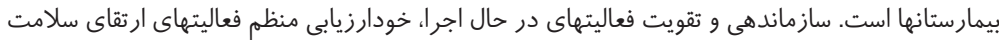

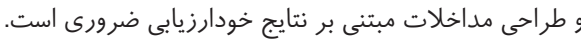

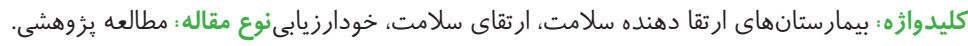

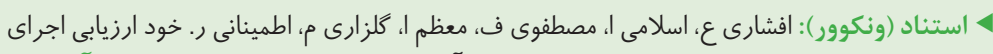

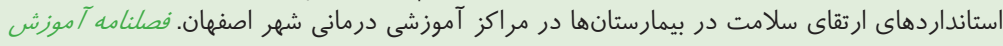
بهداشت و/رتقاء سلامت. بهاييز

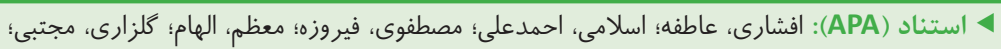

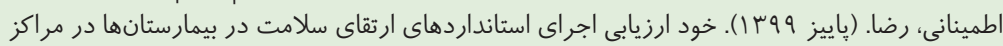

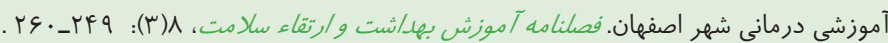

عاطفه افشارى

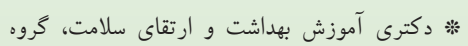

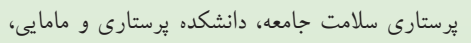

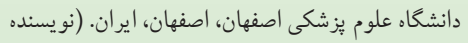
afshar.atefe@yahoo.com

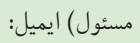

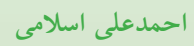
دانشيار آموزش بهداشت و ارتى ارتقاى سلامت، كروه

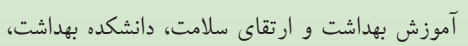
دانشكاء علوم يزشكى اصفهان، اصفهان، ايران. فيروزه مصطفوى دانئ علوم بزني دانشيار آموزش بهداشت و ارتقاى آماى سلامت، كروه

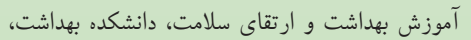
دانشكاء علوم بزشكى اصفهان، اصفهان، ايران. الهام معظم متخصص يزشكى اجتماعى، مركز تحقيقات بيشكيرى

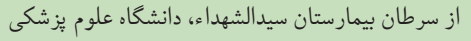
اصفهان، اصفهان، ايران. مجتبى كلزارى اصني

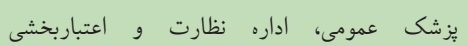

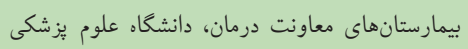
اصفهان، اصفهان، ايران.

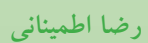
دكترى تغذيه، معاونت مالى و ادارى، دانشكا، علوم يز شكى اصفهان، اصفهان، ايران.

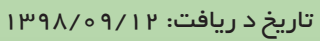

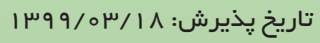


بين المللى HPH مى باشند( ا, Y). در ايران نيز باوجود راه اندازى

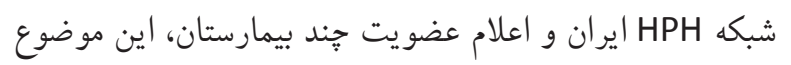

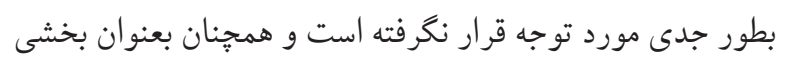

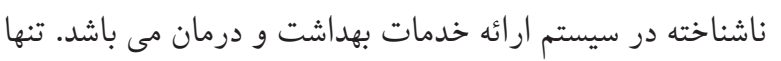

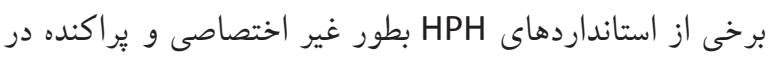

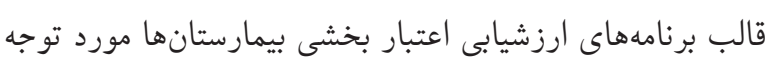
قرار گرفته است (ه). در يك بر رسى مشخص شد اكد اكثر متخصصان

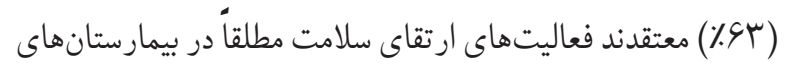

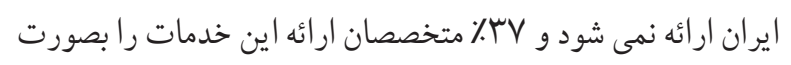

بر اكنده و غيرسازمان يافته دانسته اند( (9).

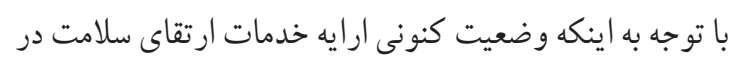

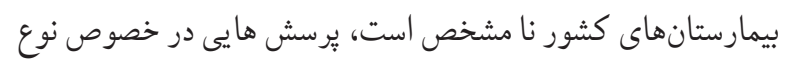

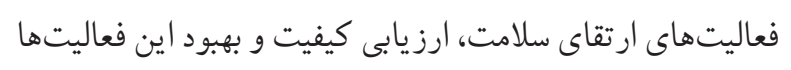

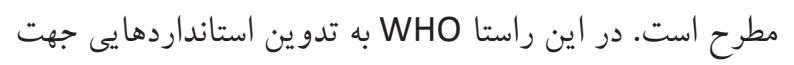
خو دارزيابى ارتقاى سلامت در بيمارستانها و توسعه ظرفيت سازمان براى بهبود فعاليتهاى ارتقاى سلامت يُرداخته است. اين استانداردها

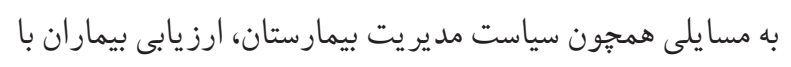

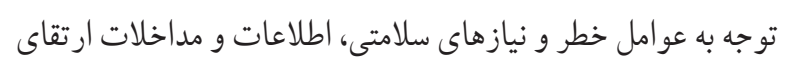
سلامت بيمار، ارتقاى سلامت در محيط كار و تداوم و همكارى

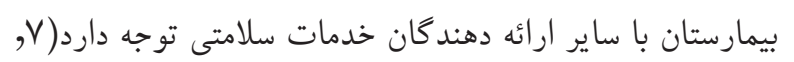

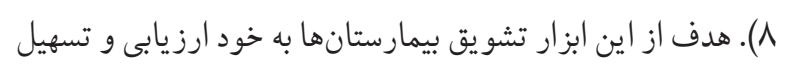

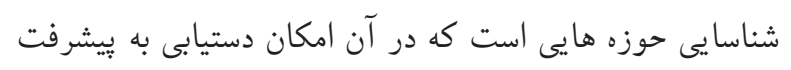

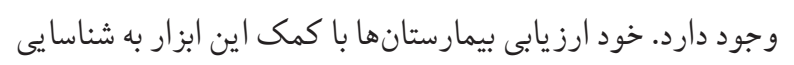

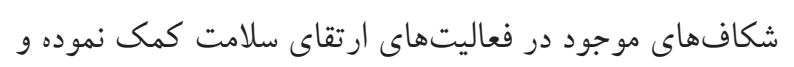
در تدوين يك برنامه عملياتى در اين خصوص كمك مي نمايك نمايد.

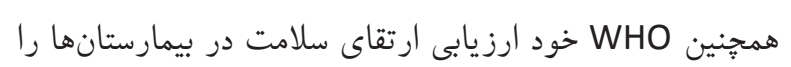

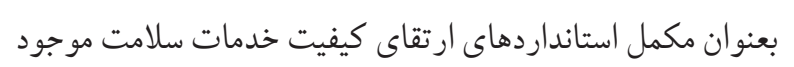

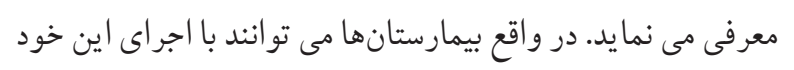

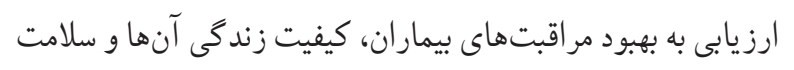

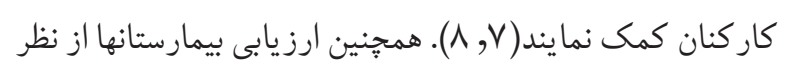

امروزه بدليل افزايش هزينههاى سلامت و بيمارىهاى مزمن ناشى از سالمندى جمعيت، رويكرد درمان محور بيمارستانها مورد انتقاد

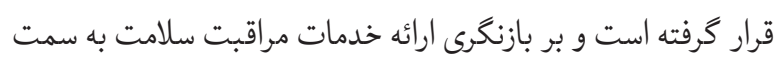
خدمات ارتقاى سلامت و بيشخيرى تاكيد مى شود. بدين ترتيب سازمان جهانى بهداشت (WHO) ' در سال 1991 بيمارستانهاى تساى

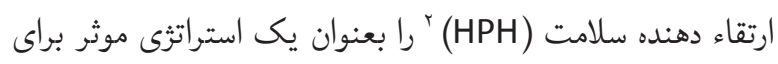

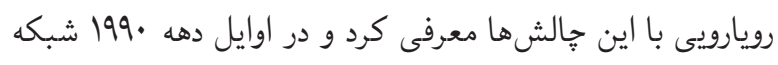

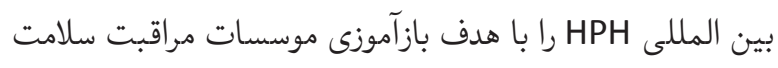

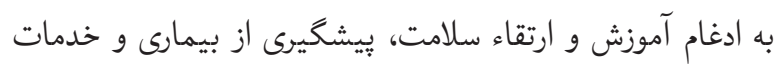

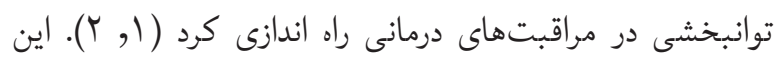

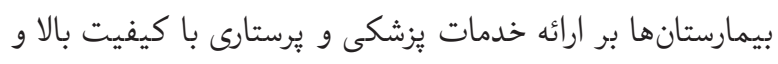

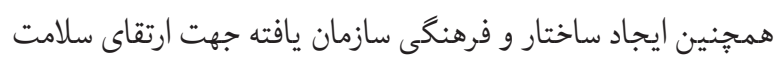

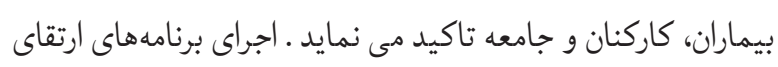

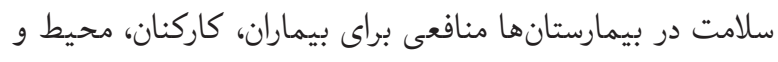

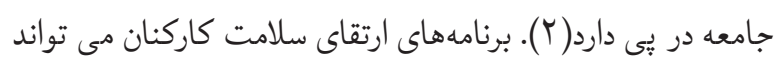

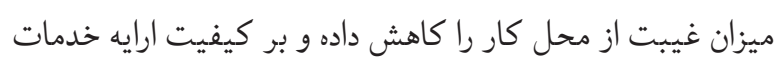

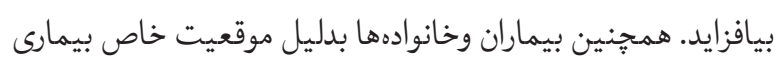

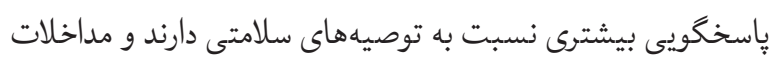

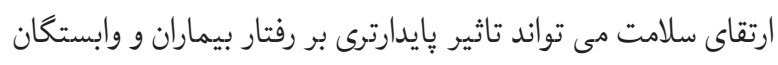

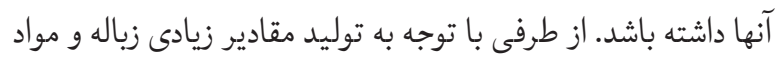

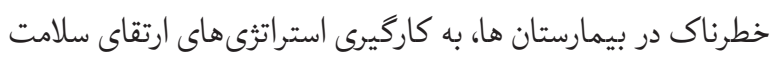
مى تواند به كاهش آلودگى محيط كمك كرده و سلامت جامعه را تامين نمايد (r). (ب). با اثبات اثربخشى مداخلات ارتقاى سلامت در بيمارستانها

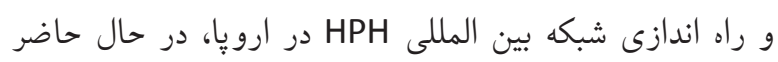
بيمارستانهاى ديكر قارهها نيز به عضويت اين شبكه در آمده و

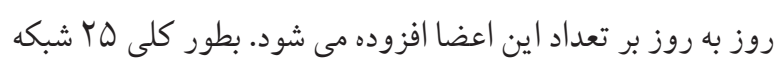
ملى /منطقه اي و بيش از . ا بيمارستان بصورت فردى عضو عضو شبكه 


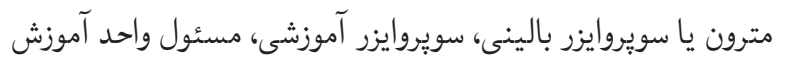

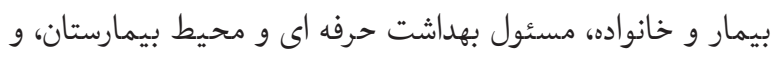

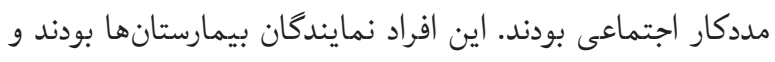
بطور مستقيم در برنامهاى ارتقاى كيفيت بيمارستان مشاركت

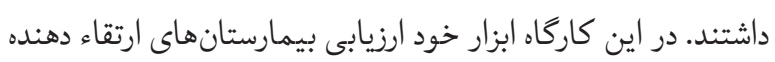

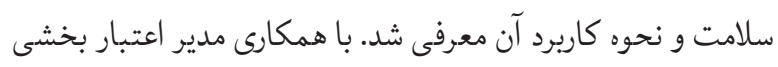

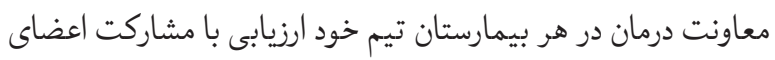
مدعو تشكيل و فرم خود ارزيابى تكميل شد.

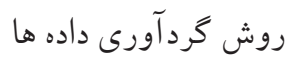

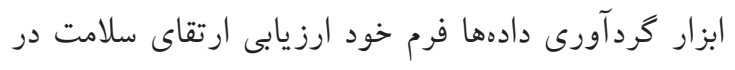

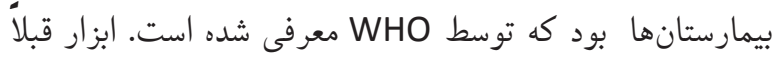
توسط نيك يُوه و همكاران ترجمه شده و در مطالعه يعقوبى و

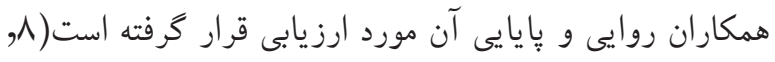

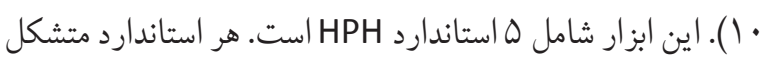
از استانداردهاى فرعى و آيتمهاى سنجش است. هر آيتم با سه إسه

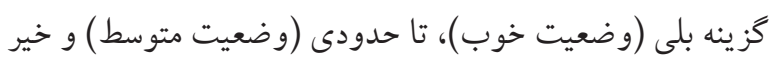

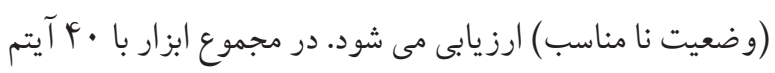

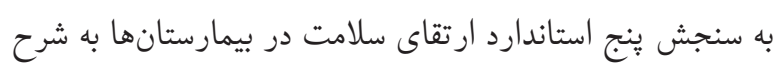

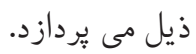

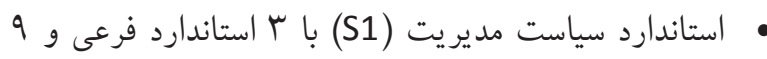

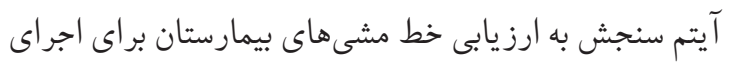
ارتقاى سلامت مى يردازد.

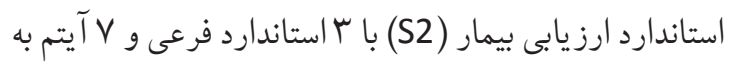

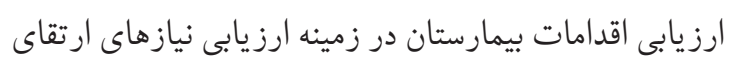

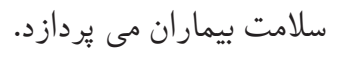

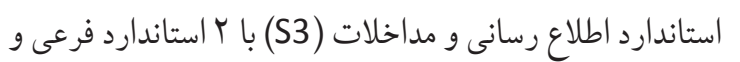

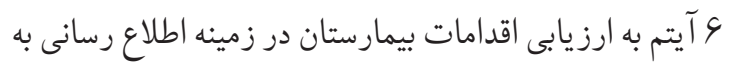
بيمار ان در مورد عوامل قابل توجه مر تبط با بيمارى يا وضعيت إنيات سلامتى شان مى بردازد. استاندارد ايجاد محيط كارى سالم (S4) با با استاندارد فرعى و ودان • ا آيتم به ارزيابى بيمارستان در زمينه فراهم نمودن شرايطى المانى
ارتقاى سلامت يكى از عوامل موثر بر استقرار بيمارستان متعهد به ارتقاى سلامت در بيمارستانهاى ايران معرفى شده است( لذا مطالعه حاضر با توجه به توصيه متون موجود و احساس نياز محقق، بعنوان فردى كه در حوزه برنامههاى جارى ارتقاى كيفيت

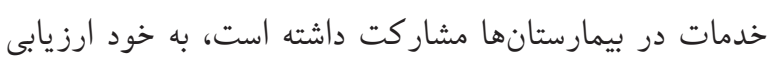
ارتقاى سلامت در بيمارستانهاى اصفهان با هدف شناسايى ميزان تناسب با استانداردها و نقاط قوت و شكاف موجود مى يردازد.

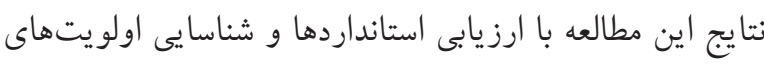
موجود، و بررسى شاخصها و نظرات و ملاحظات اضافه شده حين

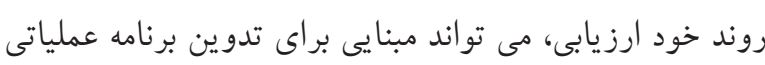
ارتقاى سلامت بيمارستانها باشد.

$$
\text { روش بررسى }
$$

در اين مطالعه توصيفى مقطعى خود ارزيابى استانداردهاى ارتقاى سلامت در بيمارستانهاى آموزشى و درمانى شهر اصفهان انجام كرفت. روش نمونه گيرى سرشمارى بود. مسئولان كليه بيمارستانهاى آموزشى درمانى شهر اصفهان جهت شركت در مطالعه دعوت شدند. نمرند

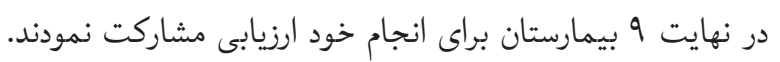
مطالعه با همكارى اداره نظارت و اعتباربخشى معاونت درمان

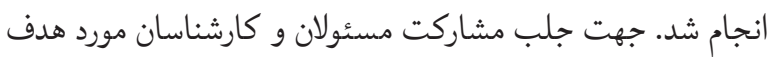

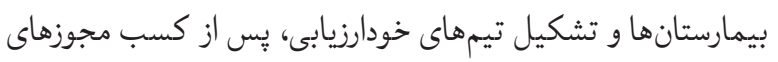

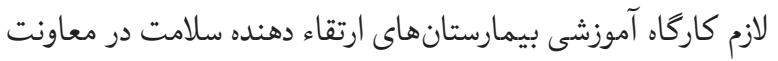

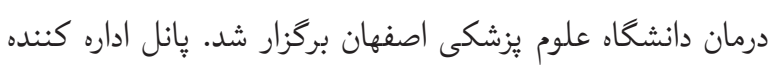

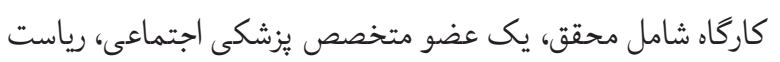
اعتبار بخشى معاونت درمان، و يك مدير بيمارستان بود. به توصيه

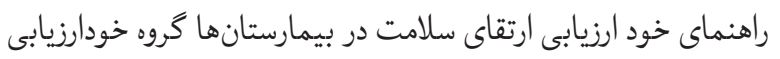

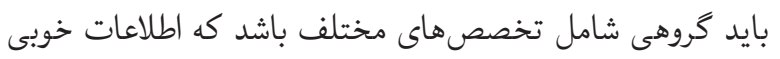

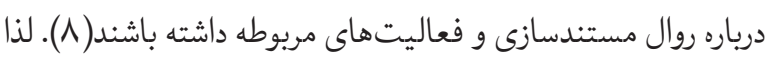
جهت تشكيل تيمهاى خود ارزيابى، اعضاى مدعو در كاركاه با توجه

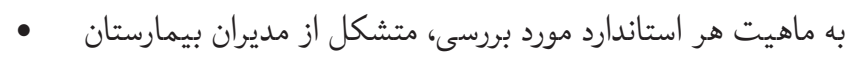

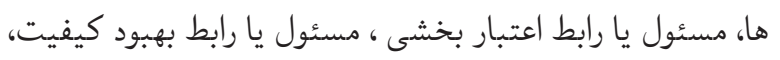


جدول ا: مشخصات بيمارستانهاى آموزشى درمانى تحت مطالعه و در شهر اصفهان و فراوانى اعضاى تيمهاى خود ارزيابى (تعداد=9)

\begin{tabular}{|c|c|}
\hline فراوانى (درصد) & 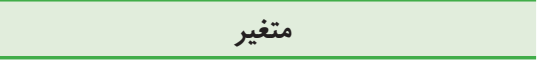 \\
\hline $\begin{array}{l}r(\% / \mu \mu) \\
\varsigma(\% \varsigma \varphi / \varphi)\end{array}$ & 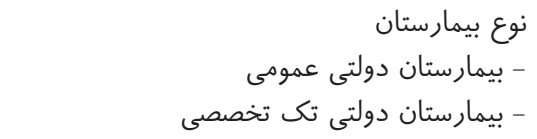 \\
\hline $\begin{array}{c}\Delta(\% \Delta \Delta / \Delta) \\
\mu(\% \mu / \mu) \\
\cdot \\
1(11 / \%)\end{array}$ & 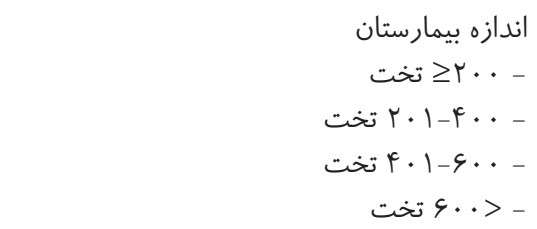 \\
\hline . & دهنده سلامت بيمارستان در شبكه بيمارستانهاى ارتقا \\
\hline$r$ & 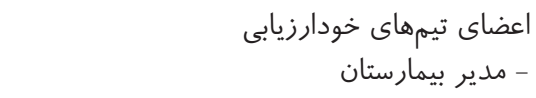 \\
\hline r & - مسئول يا رابط اعتبار بخشى و بهبود كيفيت \\
\hline 4 & - مترون يا سويروايزر بالينى، \\
\hline 9 & - سويروايزر آموزشى، س س \\
\hline 9 & - مسئول واحد آموزش بيمار و خانواده، \\
\hline 9 & - مسئول بهداشت حرفه اى و محيط، \\
\hline \& & 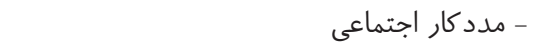 \\
\hline
\end{tabular}

بطور كلى نتايج جداول 9-Y نشان مى دهد تيمهاى خود ارزيابى

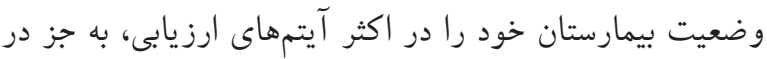
استاندارد ((مداخلات و اطلاع رسانى بيمار)) ، متوسط ارزيابى كردند.

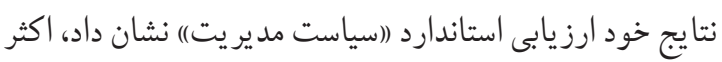

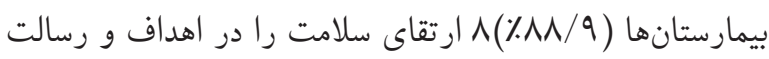
خود ذكر نموده اند. ه بيمارستان ( / /هـ\%) در برنامههاى ارتقاى كيفيت خود وجود برنامههاى ارتقاى سلامت بيماران، كاركنان و

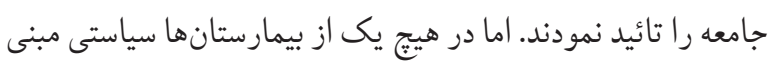

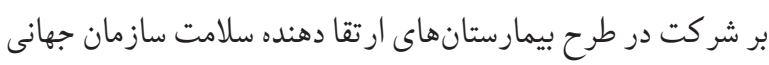
بهداشت و اختصاص بودجه مشخص براى خدمات ارتقاى سلامت

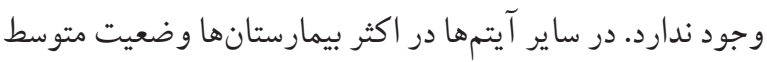

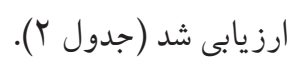

براى ايجاد يك محيط كارى سالم مى يردازد.

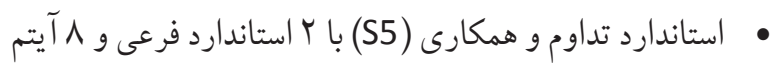
به ارزيابى بيمارستان در زمينه همكارى با ديكر ارايه كنند كان خدمات سلامتى و تداوم مراقبت بيمار مى يردازد.

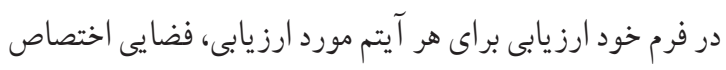

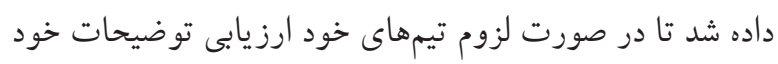

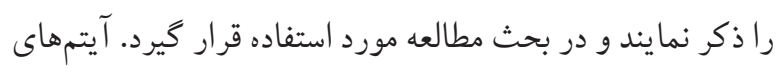

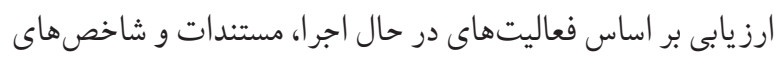
موجود ياسخ داده شدند. آناليز داده ها: به منظور خود ارزيابى بيمارستانها بر اساس استانداردهاى ارتقاى ليز

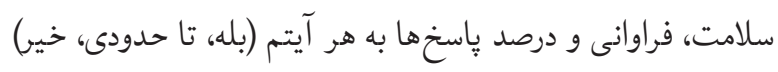

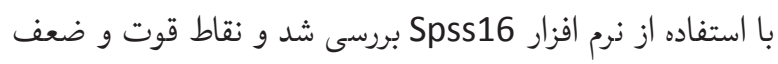
بيمارستانها شناسايى شد. ملاحظات اخلاقى و انسانى طرح: اين مطالعه در كميته اخلاق معاونت يُوهشى دانشخاه علوم IR.MUI. يزشكى اصفهان به شماره طرح

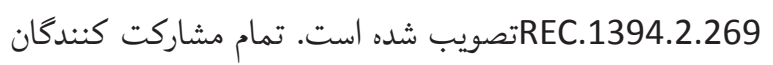
با رضايت شخصى و كلامى خود در مطالعه شركت نمودند. به

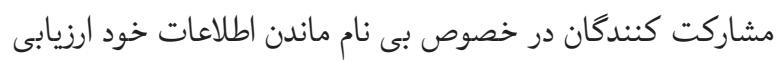
بيمارستانها اطمينان داده شد. بافته ها مشخصات بيمارستانهاى آموزشى درمانى تحت مطالعه و فراوانى

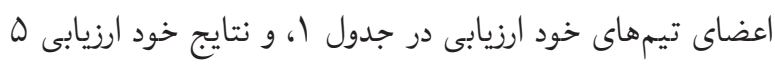

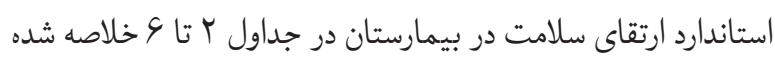
است. اكثر بيمارستانها (99/V\%) 99 دولتى تك تخصصى بودند.

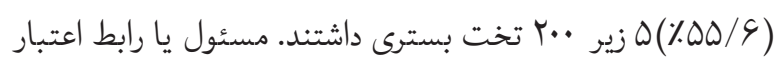

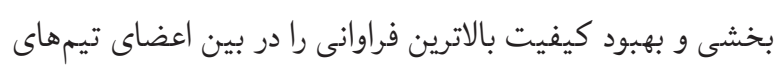
خود ارزيابى داشتند (جدول ()). 
جدول r: نتايج خود ارزيابى استاندارد سياست مديريت در بيمارستانهاى آموزشى درمانى شهر اصفهان (تعداد=9)

\begin{tabular}{|c|c|c|c|c|}
\hline $\begin{array}{l}\text { خ } \\
\text { (\%) F }\end{array}$ & $\begin{array}{l}\text { تا حدودى } \mathrm{F} \\
\text { (\%) }\end{array}$ & بله & عناصر قابل سنجش & 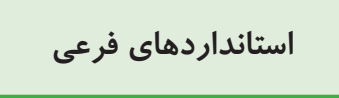 \\
\hline · & $1(11 / 1)$ & $\wedge(\wedge \wedge / 9)$ & اهداف و ماموريت ذكر شده بيمارستان شامل ارتقاى سلامت & \multirow{4}{*}{ ارتقاى سلامت مسئوليت راى شناسايى } \\
\hline $9(1 \cdots)$ & · & · & طرح بيمارستانهاى بيمار ستان دهنده سلامت سال سذشته براى شان شر كت دران بهان & \\
\hline · & $\mathcal{F}(\mathcal{F} F / F)$ & $\Delta(\Delta \Delta / \varsigma)$ & 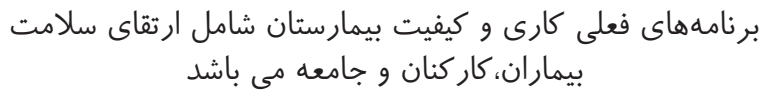 & \\
\hline · & $\mathrm{V}(\mathrm{V} / \mathrm{A})$ & $r(Y r / Y)$ & 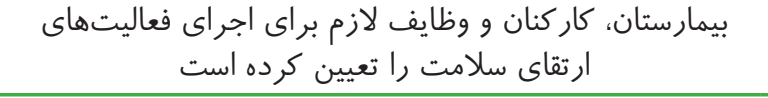 & \\
\hline$\Delta(\Delta \Delta / \varepsilon)$ & $\mathcal{F}(\mathcal{F} F / F)$ & . & بودجه مشخص براى خدمات ارتقاى سلامت وجود دارد & \multirow{3}{*}{ 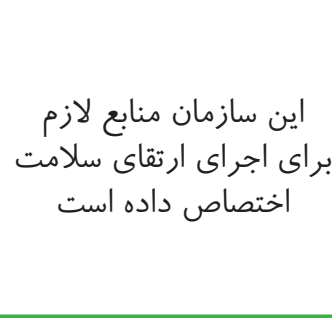 } \\
\hline $1(11 / 1)$ & $\wedge(\wedge \wedge / 9)$ & $\cdot$ & 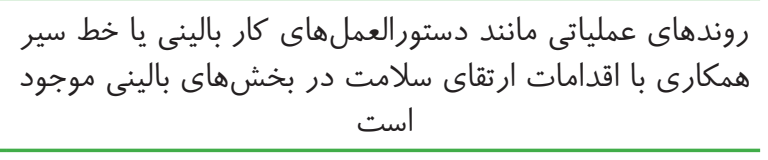 & \\
\hline$T(r Y / T)$ & $\mathrm{V}(\mathrm{V} / \mathrm{A})$ & . & ساختارها و تسهيلات خاص لازم، برات براى ارتقاى سلامت شامل & \\
\hline$\varphi(F \varphi / F)$ & $\Delta(\Delta \Delta / \varepsilon)$ & . & 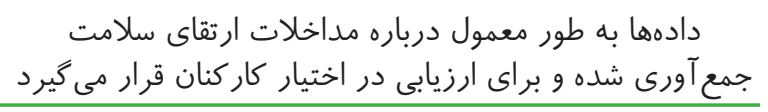 & \multirow{2}{*}{ 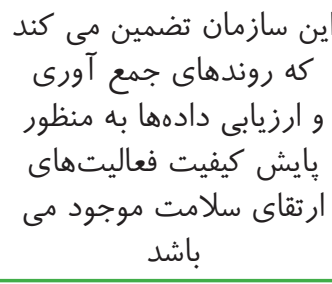 } \\
\hline$\mu(\mu \mu / \mu)$ & $\Delta(\Delta \Delta / \varsigma)$ & $1(11 / 1)$ & برنامهاى براى ارزيابى كيفيت فعاليتهاى ارتقاى سلامت بنا & \\
\hline$r F(r q / \varphi)$ & $f \backslash(\Delta \cdot / \varphi)$ & $19(19 / V)$ & خود ارزيابى عناصر استاندارد سياست مديريت & 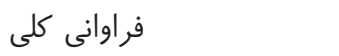 \\
\hline
\end{tabular}

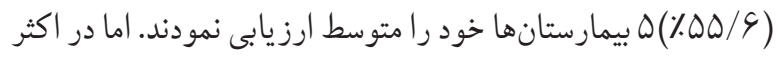

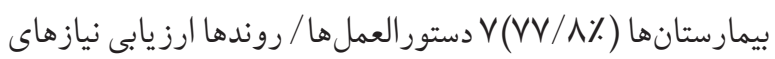
ارتقاى سلامت بيمار مورد تجديد نظر قرار نغر فته است.

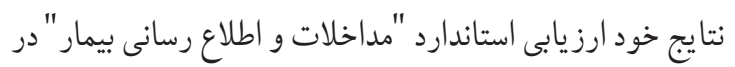

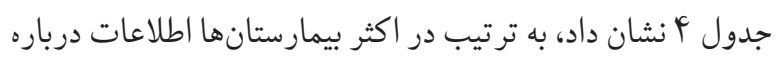

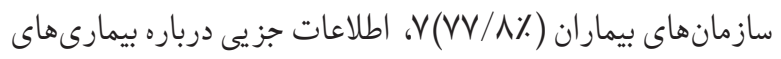

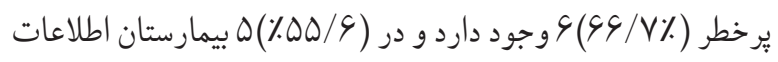
ارايه شده به بيمار در برونده ثبت مى شود. در ساير آيتمها، وضعيت متوسط ارزيابى شد.
بر اساس جدول rا، نتايج خود ارزيابى استاندارد "ارزيابى بيمار"

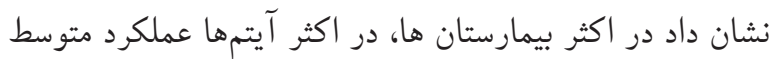

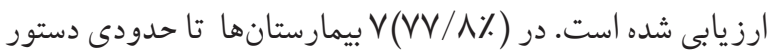

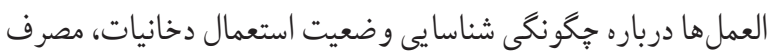
الكل، وضعيت تغذيه، وضعيت روانى اجتماعى و اقتصادى موجود

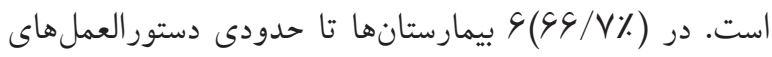
شناسايى نيازهاى ارتقاى سلامت گروههاى بيماران وجود دارد. همجنين در خصوص وجود دستور العمل هاى ارزيابى مجدد نيازهاى نهاي

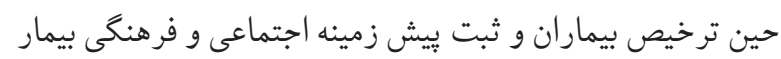


جدول "ّ: نتايج خود ارزيابى استاندارد "ارزيابى ييمار" در بيمارستانهاى آموزشى درمانى شهر اصفهان (تعداد=V)

\begin{tabular}{|c|c|c|c|c|}
\hline $\begin{array}{l}\text { خ } \\
\text { (\%) F }\end{array}$ & $\begin{array}{l}\text { تا حدودى } \mathrm{F} \\
\text { (\%) }\end{array}$ & (\%) F & عناصر قابل سنجش & استانداردهاى فرعى \\
\hline$\Gamma(Y Y / Y)$ & $\vee(\vee \vee / \wedge)$ & · & 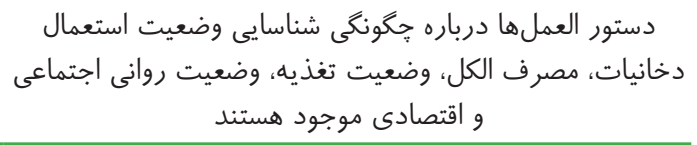 & \multirow{3}{*}{ 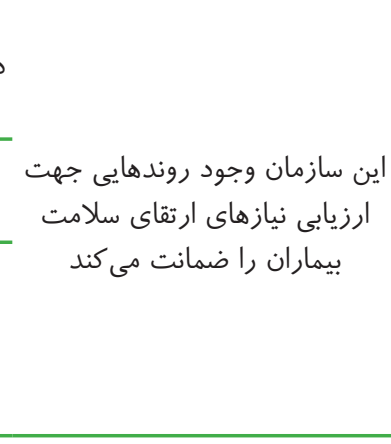 } \\
\hline$\vee(\mathrm{V} / \Lambda)$ & $r(r Y / r)$ & · & در طول سال گذشته دستور العملها / روندها مورد تجديد نظر & \\
\hline $1(11 / 1)$ & $G(\varsigma \varphi / V)$ & $r(r Y / Y)$ & 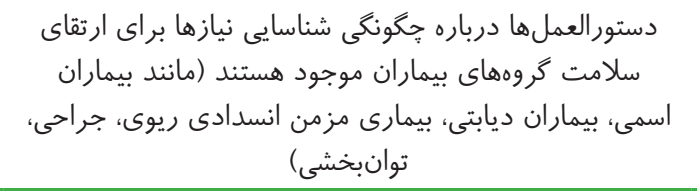 & \\
\hline$\mu(\mu / \mu)$ & $\mu(\mu / \mu)$ & 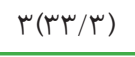 & اين ارزيابى در يرونده بيمار هنگام يذيرش ثبت مىشود & \multirow[b]{2}{*}{ 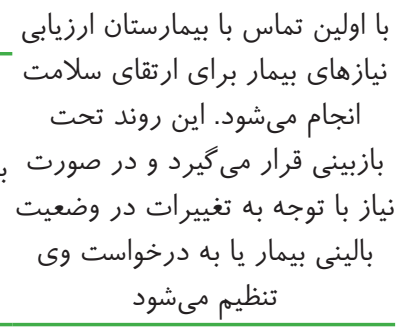 } \\
\hline$r(r Y / r)$ & $\Delta(\Delta \Delta / \varsigma)$ & $r(Y Y / Y)$ & 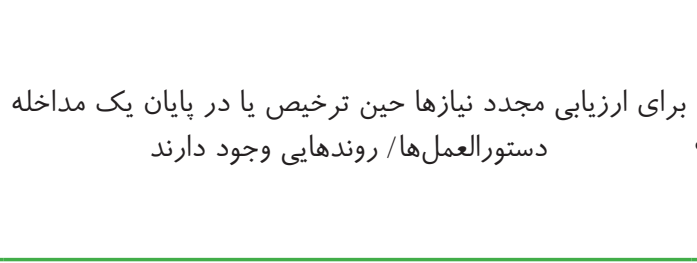 & \\
\hline$\mu(\mu / \mu)$ & $\mu(\mu / \mu)$ & $\mu(\mu r / \mu)$ & اطلاعات يزشك ارجاع كنده يا ديخر منابع مرتبط در يرونده & \multirow{2}{*}{ 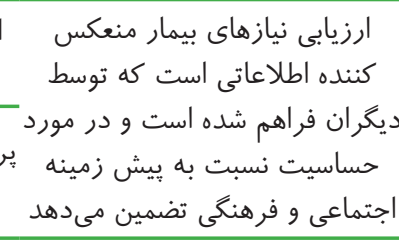 } \\
\hline$\mu(\mu r / \mu)$ & $\Delta(\Delta \Delta / \varsigma)$ & $1(11 / 1)$ & برونده بيمار بيش زمينه اجتماعى و فرهنكى وى را بطور مناسب & \\
\hline r & rI (Fq/r) & $\|(\mid V / F)$ & خود ارزيابى عناصر استاندارد ارزيابى بيمار & 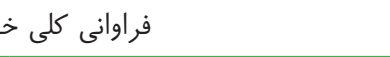 \\
\hline
\end{tabular}

جدول عا: نتايج خود ارزيابى استاندارد " اطلاع رسانى و مداخلات " در بيمارستانهاى آموزشى درمانى شهر اصفهان (تعداد=ع)

\begin{tabular}{|c|c|c|c|}
\hline $\begin{array}{c}\text { خ } \\
(\%) \mathrm{F}\end{array}$ & 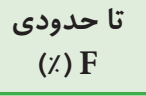 & بله & 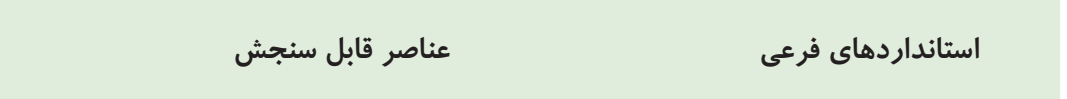 \\
\hline . & $\mathcal{F}(\mathcal{F} / \mathcal{F})$ & $\Delta(\Delta \Delta / \varepsilon)$ & اطلاعات ارايه شده به بيمار در پرونده وى ثبت مىشود \\
\hline$\Gamma(Y Y / Y)$ & $\Delta(\Delta \Delta / \varsigma)$ & $r(r Y / Y)$ & فعاليت هاى ارتقاى سلامت و نتايج مورد انتظار در اين \\
\hline$Y(Y Y / Y)$ & $\mathcal{F}(\mathcal{F} / \mathcal{F})$ & r(س/ץ) & 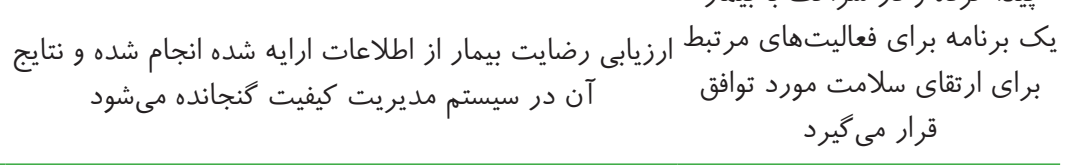 \\
\hline $1(11 / 1)$ & $\mathcal{F}(\mathcal{F} \mathbb{F} / \mathcal{F})$ & $\mathcal{F}(\mathcal{F} / \mathcal{F})$ & اطلاعات سلامتى عمومى موجود است \\
\hline . & (ץ/س & $\varsigma(\varsigma \hookrightarrow / V)$ & اطلاعات جزيى درباره بيمارىهاى پرخطر موجود است \\
\hline $1(11 / 1)$ & $1(11 / 1)$ & $\mathrm{V}(\mathrm{V} \mathrm{V} / \mathrm{\Lambda})$ & 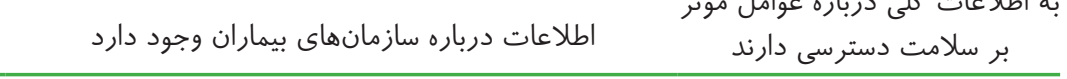 \\
\hline $9(11 / 1)$ & rI(rN/q) & $r V(\Delta \cdot)$ & فراوانى كلى خود ارزيابى عناصر استاندارد اطلاع رسانى و مداخلات \\
\hline
\end{tabular}


در جدول ه خود ارزيابى استاندارد ((ا يجاد محيط كارى سالم)" در آيتم آكاهى كار كنان از محتواى سياست ارتقاى سلامت سازمان

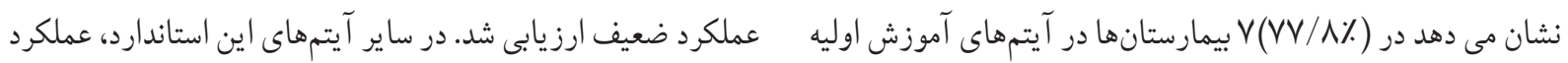

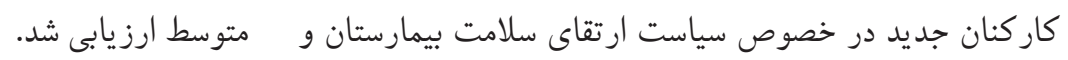

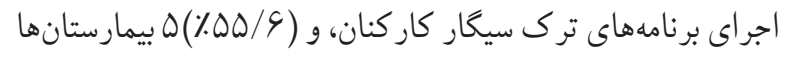

جدول ه: نتايج خود ارزيابى استاندارد (ايجاد محيط كارى سالم) در ييمارستانهاى آموزشى درمانى شهر اصفهان (تعداد= • I)

\begin{tabular}{|c|c|c|c|}
\hline $\begin{array}{l}\text { خ } \\
(\%)\end{array}$ & $\begin{array}{l}\text { تا حدودى } \mathrm{F} \\
\text { (\%) F }\end{array}$ & (\%) F & 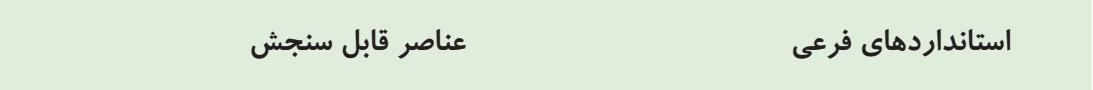 \\
\hline$r(Y r / Y)$ & $\mathrm{V}(\mathrm{V} / \mathrm{A})$ & · & اين سازمان توسعه و اجراى طرح شرايط كارى با رهنمودها و شاخصهاى ملى / منطقهاى سازگار \\
\hline · & $\mathrm{V}(\mathrm{V} / \mathrm{A})$ & $r(Y Y / Y)$ & 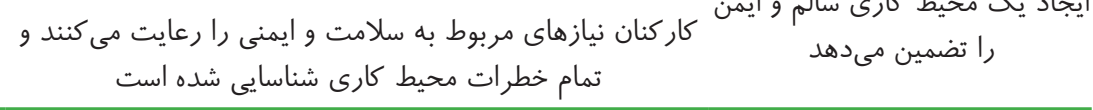 \\
\hline $\mathrm{V}(\mathrm{V} \mathrm{V} / \mathrm{\Lambda})$ & $r(Y Y / Y)$ & $\cdot$ & 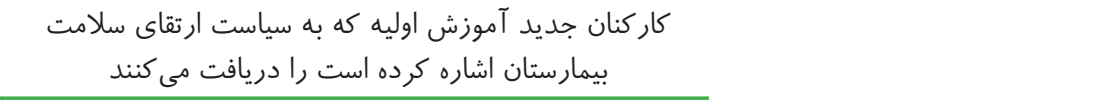 \\
\hline$\Delta(\Delta \Delta / \varsigma)$ & $F(F F / F)$ & · & 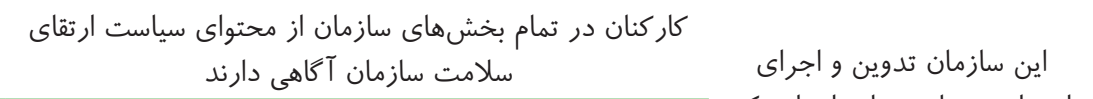 \\
\hline (r/س) & $G(G S / V)$ & · & 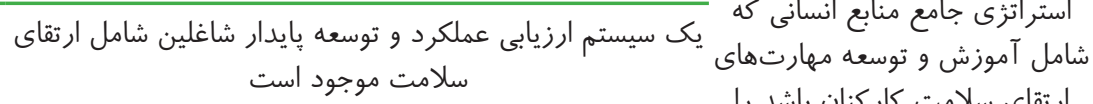 \\
\hline $1(11 / 1)$ & $\Delta(\Delta \Delta / \varsigma)$ & $\Gamma(\mu \mu / \mu)$ & اقدامات كارى روندها و دستورالعملها توسط گروههاى جند تدوين شدهاند \\
\hline $1(11 / 1)$ & $G(G \varphi / V)$ & $r(r Y / r)$ & كار كنان در سياستخذارى بيمارستان، رسيدگى و مرور آن شر كت \\
\hline$F(F F / F)$ & س) & $r(Y r / Y)$ & سياستهاى آكًاهى كار كنان از مسايل سلامتى موجود است \\
\hline $\mathrm{V}(\mathrm{V} \mathrm{V} / \mathrm{\Lambda})$ & $r(Y Y / Y)$ & $\cdot$ & برنامههاى ترك سيگار ارايه شده است \\
\hline$\mu(\mu r / \mu)$ & $G(s G / V)$ & . & 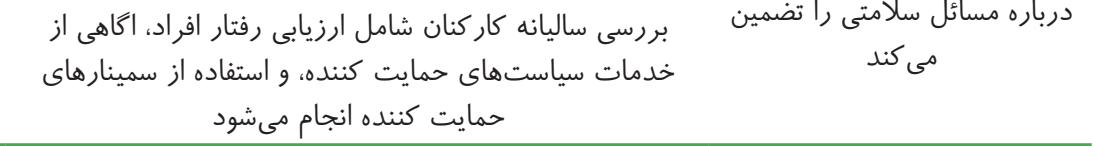 \\
\hline س & $F \wedge(\Delta \mu / r)$ & $9(1 \cdot)$ & فراوانى كلى خود ارزيابى عناصر استاندارد ايجاد محيط كارى سالم \\
\hline
\end{tabular}

خود ارزيابى استاندارد "تداوم و همكارى" در جدول 9 نشان از بيمارى و نيازهاى سلامتى بيمار و مداخلات انجام شده از سازمان

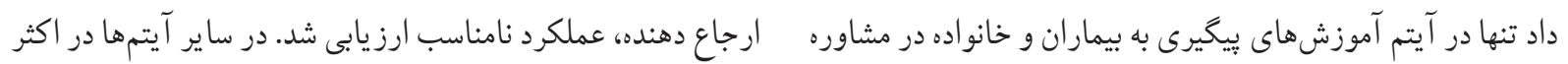

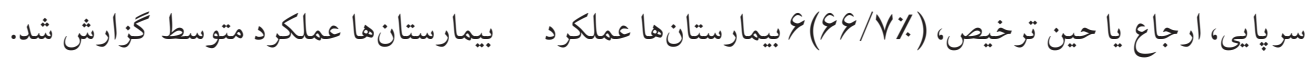
خود را مناسب ارزيابى كردند. در (99/V\%)

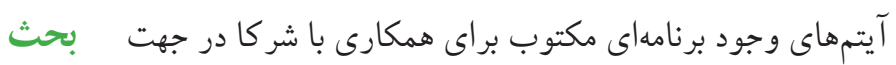

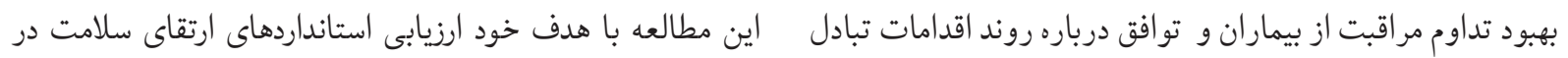

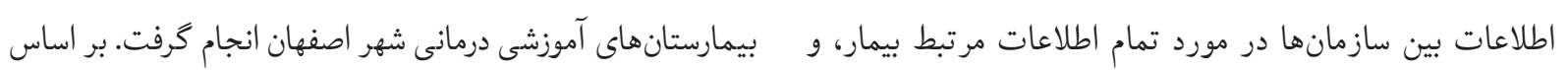

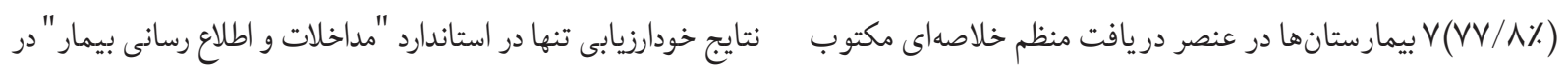




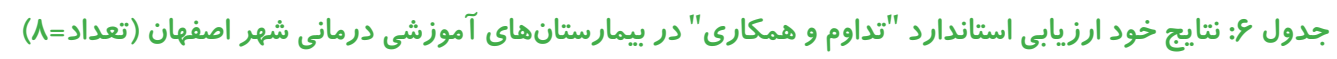

\begin{tabular}{|c|c|c|c|c|}
\hline 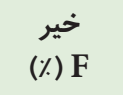 & $\begin{array}{l}\text { تا حدودى } \\
\text { (\%) F }\end{array}$ & بله & عناصر قابل سنجش & 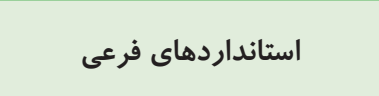 \\
\hline $1(11 / 1)$ & $G(\zeta G / V)$ & $r(r Y / r)$ & هيات مديره به برنامه سياست سلامت منطقهاى اهميت مىدهد & \multirow{4}{*}{ 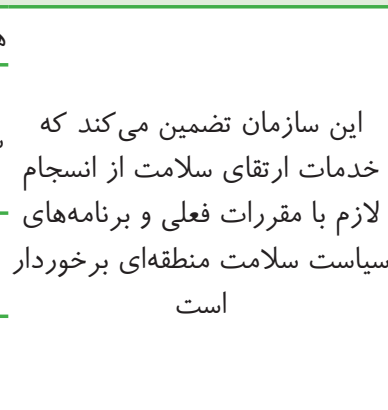 } \\
\hline $1(11 / 1)$ & $G(G G / V)$ & $\Gamma(r Y / Y)$ & 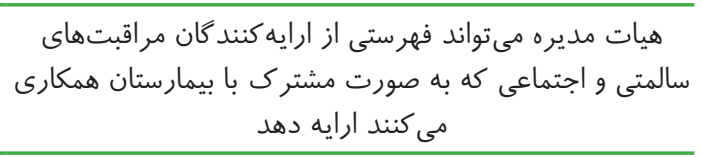 & \\
\hline ) & $G(\zeta G / V)$ & . & 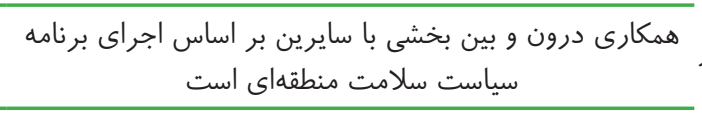 & \\
\hline$G(\zeta \hookrightarrow / V)$ & ( & . & 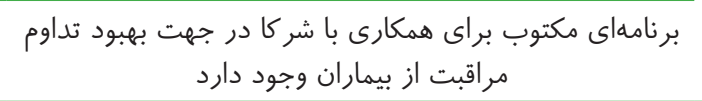 & \\
\hline . & r & $\zeta(\varsigma \zeta / V)$ & 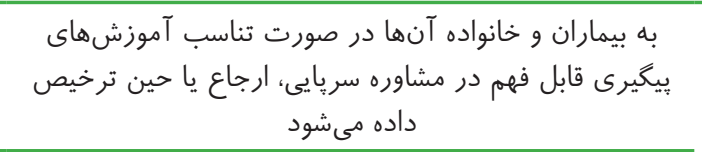 & \multirow{3}{*}{ 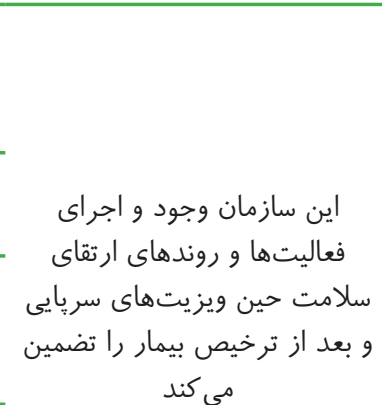 } \\
\hline$G(\zeta G / V)$ & & . & 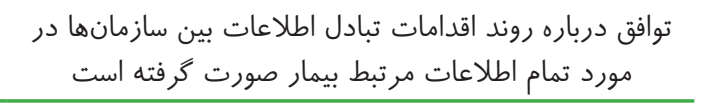 & \\
\hline$V(V V / \Lambda)$ & $Y(Y Y / Y)$ & . & 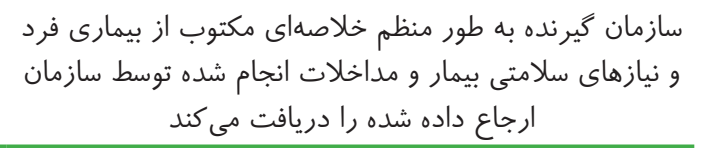 & \\
\hline
\end{tabular}

\begin{tabular}{|c|c|c|c|}
\hline ( & $\Delta(\Delta \Delta / \varsigma)$ & $1(11 / 1)$ & 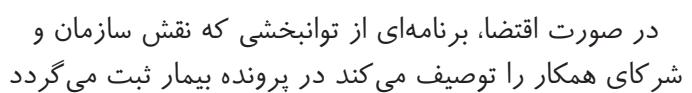 \\
\hline
\end{tabular}

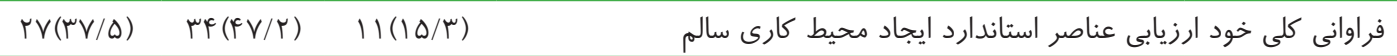

اكثر عناصر عملكرد مناسب گزارش شد و عمده نقاط قوت بيمارستانها وهله اول موضوع بيمارستانهاى ارتقا دهنده سلامت در كشور جديد

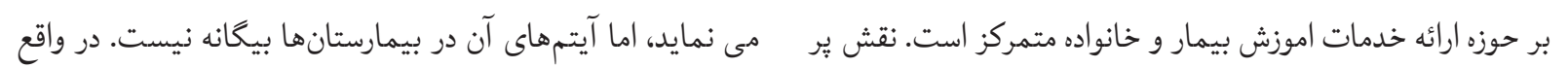

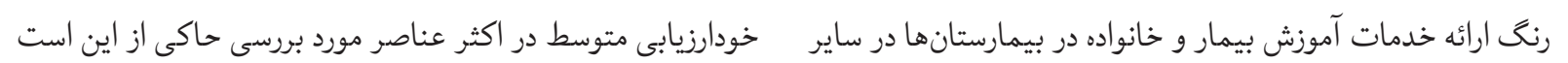

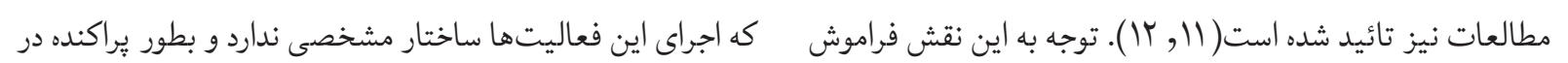

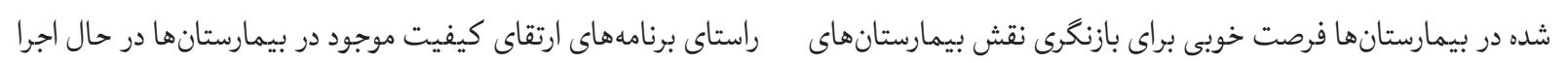

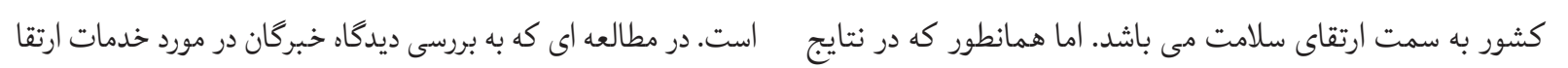

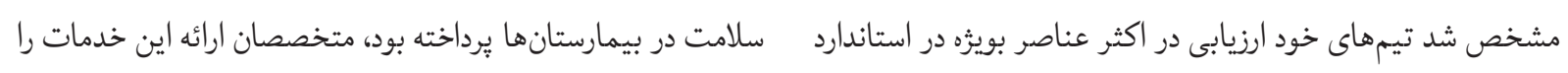

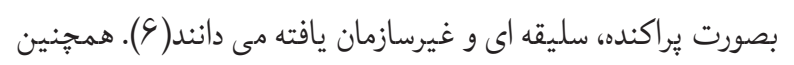

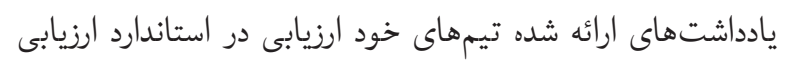

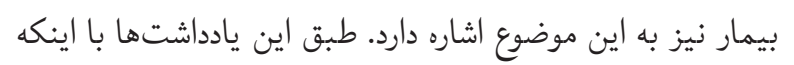

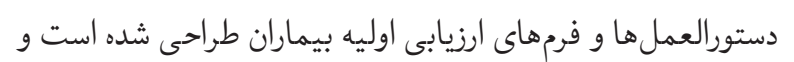

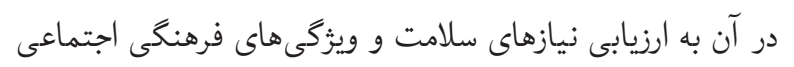
بيماران برداخته مى شود، اما اين دادهها در نهايت مورد استفاده قرار ارزيابى بيمار، وضعيت اجراى استانداردها را متوسط ارزيابى نمودند.

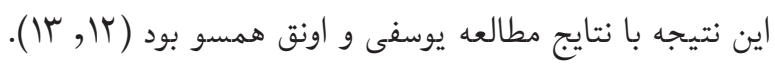

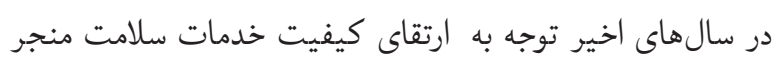

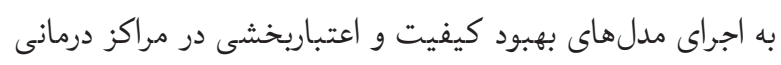

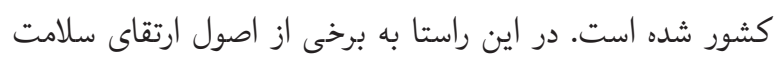

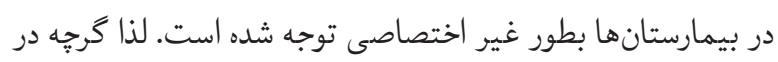


طر احى مداخلات ترك سيعار كار كنان در برنامه عملياتى ارتقاى سلامت بيمارستان ها بيشنهاد مى گردد.

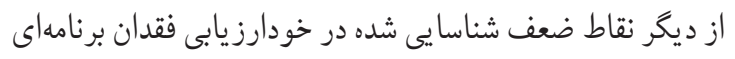
مكتوب براى همكارى با شر كاو روند مشخص براى تبادل اطلاعات

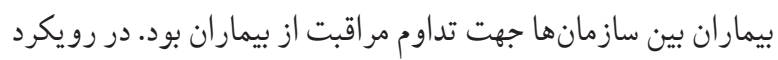
بيمارستانهاى ارتقا دهنده سلامت، بيمارستانها در جهار سطح تعريف مى شوند. هدف نهايى رساندن بيمارستانها به سطح جهار است، يعنى جايى كه علاوه بر سلامت بيماران و كار كنان براى حوزه سلامت بهات

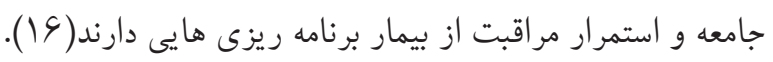

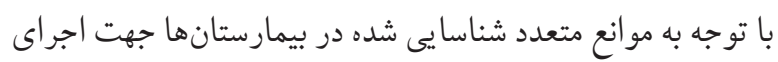
ارتقاى سلامت، شايد حركت به سمت بيمارستانهاى سطح جهار در شرايط فعلى كمى ايده آل نكر انه باشد( (F) أ). اما استفاده تصميم

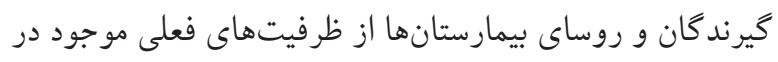

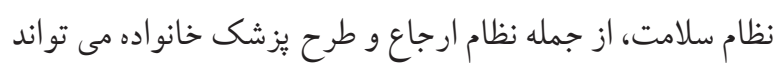
در توسعه نقش ارتقاى سلامت جامعه بيمارستانها كمك كننده

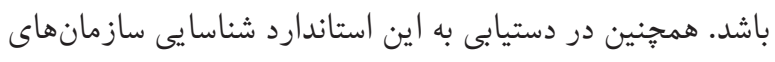
همكار در جامعه به تنهايى كافى نيست. تدو ين دستور العملهاى دهاى

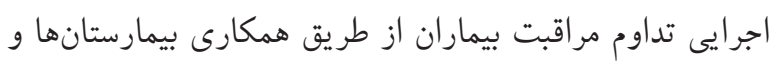

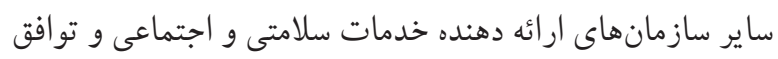
بر آن بين شر كا از اقداماتى است كه توصيه مى كردد.

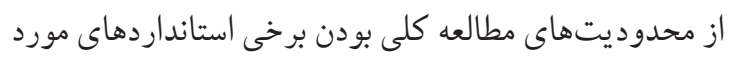
ارزيابى، فقدان راهنماى مشخص جهت خود ارزيابى و كمبود

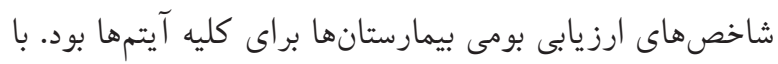

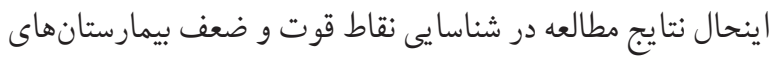

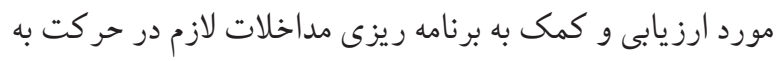
سمت بيمارستانهاى ارتقا دهنده سلامت كمك كننده مى باشد. تدوين

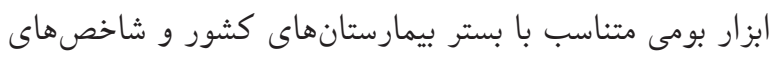

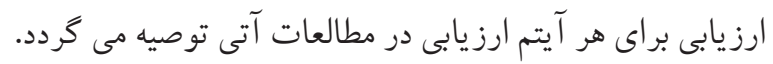
نتيجاه كيرى در اكثر بيمارستانها وضعيت به لحاظ وجود هدف ارتقاى سلامت در رسالت بيمارستان، وجود اطلاعات ساير سازمانهاى بيماران، ارائه
نخواهد كرفت. عضويت بيمارستانها در شبكه بيمارستانهاى ارتقا دهنده سلامت كه از نقاط ضعف بيمارستانها در مطالعه شناسايى شد، مى تواند راه كارى براى اين مساله و هدايت موثرتر فعاليتهاى

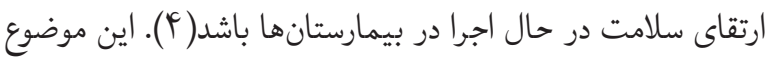

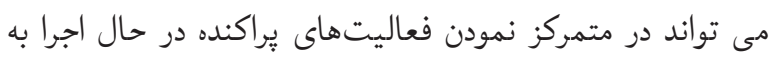

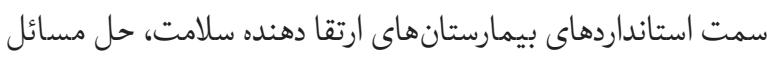
تامين بودجه ويزه خدمات ارتقاى سلامت و تدوين دستورالعملها و كايدلاينها مشخص براى اجراى نقش ارتقاى سلامت بيمارستانها كمك كننده باشد. كمبود آكاهى كار كنان از محتواى سياست ارتقاى سلامت سازمان و عدم آموزش كار كنان جديد در خصوص سياست ارتقاى سلامت بيمارستان از نقاط ضعف بيمارستانهاى مورد مطالعه در استاندارد حوزه كاركنان بود. در مطالعه اى در خصوص شناسايى موانع و

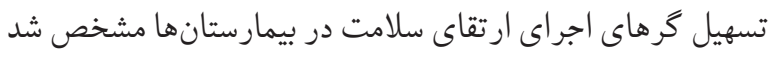

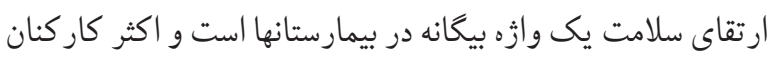
و مديران از برنامهها و فعاليتهاى ارتقاى سلامت اطلاعى ندارند (IF). بينش و در ك كاملى از اهداف، فلسفه، و فعاليتهاى ارتقاى سلامت

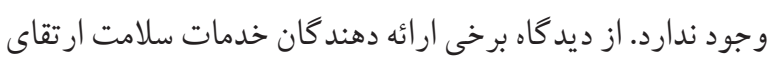

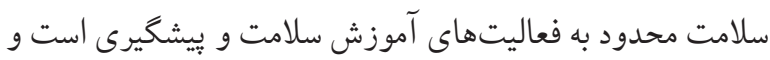

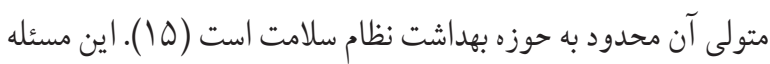

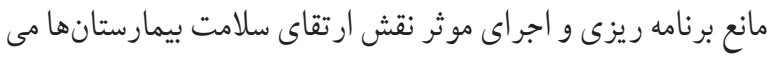

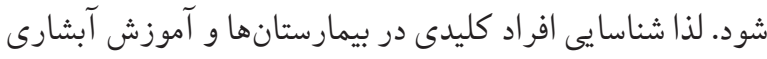
كار كنان جهت ايجاد فرهنگ ارتقاى سلامت در بيمارستانها توصيه مى شود( ( I ). برنامه ريزى و مداخله ترى سيكار كار كنان بطور ويزه در استانداردهاى ارتقاى سلامت حوزه كاركنان توجه شده است. اما بر اساس نتايج مطالعه در اكثر بيمارستانها مداخله ايى در اين خصوص انجام نكرفته است. يوسفى و همكاران نيز در مطالعه خود

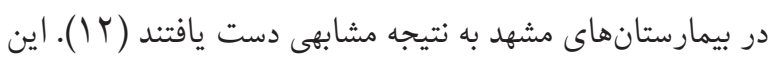
مداخلات ممكن است بدليل موانع فرهنگى اجتماعى در بيمار ستانها

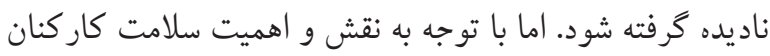
در ييشبرد اهداف سازمان و ذكر صريح اين عنصر در استانداردها 


$$
\begin{aligned}
& \text { غيرسازمان يافته برخى فعاليتهاى ارتقاى سلامت در بيمارستانها }
\end{aligned}
$$

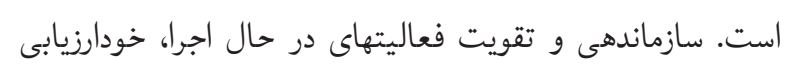

$$
\begin{aligned}
& \text { منظم فعاليتهاى ارتقاى سلامت و طراحى مداخلات مبتنى بر نتايج } \\
& \text { خودارزيابى ضرورى است. }
\end{aligned}
$$

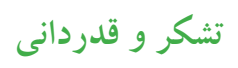

$$
\begin{aligned}
& \text { نويسندكان مقاله نهايت تشكر خود را از معاونت تحقيقات و فناورى } \\
& \text { دانشخاه علوم يُشكى اصفهان جهت حمايت طرح (شماره طرح: }
\end{aligned}
$$

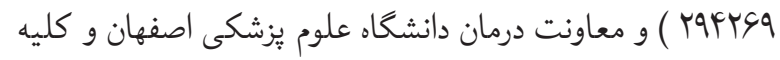

$$
\begin{aligned}
& \text { اعضاى شركت كننده در تيمهاى خود ارزيابى در بيمارستانهاى } \\
& \text { آموزشى درمانى دانشكاه علوم يزشكى اصفهان اعلام مى دارد. } \\
& \text { تضاد منافع: سهم تمامى نويسندگان دراين مطالعه يكسان است دمان } \\
& \text { وهيجگُونه تضاد منافعى وجود ندارد . }
\end{aligned}
$$

\section{References}

1. World Health Organization.The International Network of Health Promoting Hospitals and Health Services: Integrating health promotion into hospitals and health services: World Health Organization: Regional Office for Europe 2007.

2. The international Network of Health Promoting Hospitals and Health Services ( $\mathrm{HPH})$. Integrating health promotion into hospitals and health services (concept, framework and organization). Translated by Nikpajuh A, Samadi B. Tehran: Institute of Contemporary Iranian prevention and health promotion; 2010 (Persian).

3. Groene O, Garcia-Barbero M. Health promotion in hospitals: Evidence and quality management. Translated by Nikpajuh Akbar. Tehran: Institute of Contemporary Iranian prevention and health promotion; 2009 (Persian).

4. World Health Organization. The International HPH Network. Available from: http//www.hphnet.org. Access August 11.2019.

5. Afshari A. Identification of Factors and Process Affecting the Adoption of Health Promotion in Hospitals Affiliated to Isfahan University of Medical Sciences: A Mixed Method Approach Based on Diffusion of Innovation, and Social Cognitive Theories [Thesis]. Isfahan University of Medical Sciences: Health collage; 2016. 263 (Persian).

6. Heidarnya M, Abachizade K, Damari B, Azargasb AA, Moghadam A. Survey of expert opinion on health promotive services to patients in hospitals affiliated

$$
\begin{aligned}
& \text { اطلاعات درباره بيمارىهاى يرخطر، ثبت اطلاعات ارايه شده در برونده }
\end{aligned}
$$

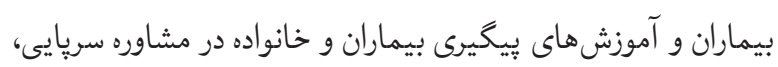

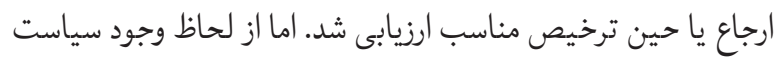

$$
\begin{aligned}
& \text { شركت در طرح بيمارستانهاى ارتقا دهنده سلامت، اختصاص بودجيه } \\
& \text { مشخص براى اين خدمات، تجديد نظر دستورالعمل هاى ارزيابى لتردي }
\end{aligned}
$$

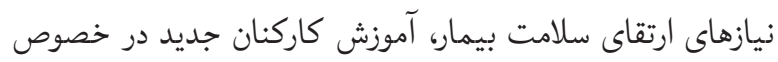

$$
\begin{aligned}
& \text { سياست ارتقاى سلامت بيمارستان، برنامههاى ترك سيعار كاركنان، } \\
& \text { آكاهى كاركنان از محتواى سياست ارتقاى سلامت سازمان، وجود } \\
& \text { برنامهاى مكتوب براى همكارى با شركاو روند مشخص براى تبادل }
\end{aligned}
$$

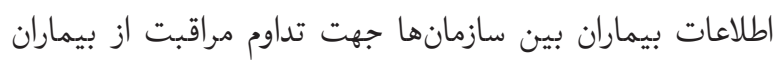

$$
\begin{aligned}
& \text { وضعيت نا مناسب ارزيابى شد. در ساير استانداردها اكثر بيمارستانها }
\end{aligned}
$$

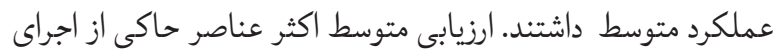

to Shahid Beheshti University and presents a model. Pajuhande journal. 2009; 14(4):183-190 (Persian).

7. Groene, Oliver. Implementing health promotion in hospitals: Manual and self-assessment forms. Copenhagen: WHO Regional Office for Europe. 2006.

8. Groene, Oliver. Implementing health promotion in hospitals: Manual and self-assessment forms. Translated by Nikpajuh A, Samadi B. Tehran: Institute of Contemporary Iranian prevention and health promotion; 2010 (Persian).

9. Yaghoubi M, Maleki MR, Javadi M. Factors affecting the establishment of health promoting hospital (hph) program in medical universities hospitals in Iran. Journal of Daneshvar. 2013; 21(1): 1-11.

10. Yaghoubi M, Javadi M. Health promoting Hospitals in Iran: How it is. JEHP. 2013; 2:41.

11. Afshari A, Mostafavi F, Keshvari M, Ahmadi-Ghahnaviye L, Piruzi M, Moazam E, et al. Health promoting hospitals: a study on educational hospitals of Isfahan, Iran. Health promotion perspectives. 2016;6(1):23.

12. Yousefi S, Vafaeenajar A, Esmaily $H$, Hooshmand E. Evaluation of General Educational Hospitals Affiliated to Mashhad University of Medical Sciences Based on the Standards of Health-promoting Hospitals. Iran J Health Educ Health Promot. 2017;5(4):320-7(Persian).

13. Onegh S, Vahdat S, Mahfouzpur S. Determining the Readiness of Hospitals in Golestan Province in Terms of Management in Establishing Standards for Health 
Promotion Hospitals. Journal Of Healthcare Management. 2018; 8(4):29-39 (Persian).

14. Afshari A, Mostafavi F, Latifi A, Ghahnaviyeh LA, Pirouzi $M$, Eslami AA. Hospitals reorientation towards health promotion: A qualitative study of barriers to and strategies for implementation of health promotion in hospitals of Isfahan, Iran. JEHP. 2018;7: 72.

15. Afshari A, Ghahnaviyeh LA, Khezeli M, Daniali SS. Health promotion perception among health-care providers working in educational hospitals of Isfahan, Iran: A Qualitative study. JEHP. 2019;8(1):144.

16. Ahangari M, Hajikhani S, Hesam S, Arvin R, Ghaziasgar M. Factors Affecting the Implementation of Health Promoting Hospitals of Tehran University of Medical Sciences: Hospital Administrators Vision. Journal of North Khorasan University of Medical Sciences. 2018;10(1):21-9 (Persian). 